\title{
RAPID ENVIRONMENTAL CHANGES IN THE WESTERN ANTARCTIC PENINSULA REGION DUE TO CLIMATE CHANGE AND HUMAN ACTIVITY
}

\author{
ZNÓJ, A. ${ }^{1}$ - ChWEDORZEWSKA, K. J. ${ }^{1}$ - ANDROSIUK, P. $^{2}$ - CUBA-DiAZ, M. ${ }^{3}$ - GIEŁWANOWSKA, I. ${ }^{2}$ \\ - KOC, J. ${ }^{2}-$ KORCZAK-ABSHIRE, M. ${ }^{1 *}$ - GRZESIAK J. ${ }^{1}-$ ZMARZ, A. $^{4}$ \\ ${ }^{1}$ Institute of Biochemistry and Biophysics PAS, Department of Antarctic Biology \\ Pawińskiego 5a, 02-106 Warsaw, Poland \\ (e-mail:mka@ibb.waw.pl,aznoj@ibb.waw.pl,kchwedorzewska@ibb.waw.pl) \\ ${ }^{2}$ Department of Plant Physiology and Biotechnology, University of Warmia and Mazury \\ Oczapowskiego 1A, 10-719 Olsztyn, Poland \\ (e-mail:i.gielwanowska@uwm.edu.pl,kocjustyna@interia.pl,piotr.androsiuk@uwm.edu.pl) \\ ${ }^{3}$ Departamento de Ciencias y Tecnología Vegetal, Universidad de Concepción \\ Juan Antonio Coloma 0201, Los Angeles, Chile \\ (e-mail:mcubaster@gmail.com) \\ ${ }^{4}$ University of Warsaw, Faculty of Geography and Regional Studies Department of \\ Geoinformatics, Cartography and Remote Sensing \\ Warsaw, Poland \\ (e-mail:azmarz@uw.edu.pl) \\ *Corresponding author \\ e-mail: mka@ibb.waw.pl \\ (Received 23 ${ }^{\text {rd }}$ Jan 2017; accepted $3^{\text {rd }}$ Jul 2017)
}

\begin{abstract}
The Antarctic and the Southern Ocean are a critically important part of the Earth system. The climatic, physical, and biological properties of this region are closely linked to other parts of the global environment. 200 years of direct human impact, recent climate amelioration and changes in the main sources and circulation of biogenic compounds as well as accumulation of industrial contaminants have significantly affected the whole ecosystem. Particularly sensitive is the region of the Western Antarctic Peninsula, which is considered to be one of the hot spots of the Earth. In this paper, we review recent literature and compare it with historical data to estimate and predict the consequences of this process. The Antarctic ecosystems can no longer be regarded as pristine. Global as well as local human influence has transgressed the barriers isolating that continent from the rest of the World, causing previously observed changes to accelerate.
\end{abstract}

\section{Introduction}

\section{The specificity of Antarctic conditions}

Antarctica is surrounded by the Southern Ocean. Together they occupy about onethird of the southern hemisphere. The Antarctic continent and associated islands are situated at a distance of nearly $1000 \mathrm{~km}$ from South America and of 4000-5000 km from Australia and South Africa. The isolation process began with the breakup of Gondwana and was enhanced and then maintained by the development of the atmospheric Polar Vortex and oceanic Antarctic Polar Front (Clarke et al., 2005; Barnes et al., 2006). Terrestrial ecosystem development is limited to only $0.34 \%$ of ice-free areas of the whole surface of Antarctica, mainly concentrated on coastal zones of the 
Antarctic Peninsula (Convey et al., 2009). This region is characterized by insular occurrence of exposed ice-free grounds and also by patchy and discontinuous soil distribution, displaying one of the harshest environmental conditions found on Earth (Convey et al., 2014). Low temperatures, limited liquid water availability, a specific light regime, elevated ultraviolet-B radiation levels, desiccating and destructively strong winds, poorly developed soils with low organic matter and nutrient content, slow organic matter decomposition, irregular nutrient distribution (from nutrient-deficient habitats to the ones extremely enriched in nutrients by e.g. huge breeding colonies of seabirds), high salinity in many locations (due to marine influences), the presence of permafrost, freeze-thaw events, cryoturbation, solifluction or ablation significantly limit the development of terrestrial communities (Chwedorzewska, 2009; Convey et al., 2014). Thus, characteristic features of Antarctic organisms are high stress tolerance, wide ecological amplitude but with minor competitive ability or investment in dispersal strategies, reduced reproductive investment and output, and extended lifespans and life cycles (Convey, 1996, 2000). Variability in abiotic conditions is recognized as a key feature affecting organism responses (e.g. Tufto, 2000). Antarctic terrestrial organisms display biochemical, physiological and anatomical adaptations that allow them to withstand prolonged periods of freezing, desiccation and abrasion (Olech, 2004; Giełwanowska and Szczuka, 2005; Wasley et al., 2006; Ochyra et al., 2008).

Most taxa are represented in the Southern Ocean, with Antarctica's shelf waters are particularly rich in this regard (Brey et al., 1994; Clarke and Johnston, 2003; Siciński et al., 2011). Moreover, biomass and productivity of both oceanic and near shore systems are massive. The Antarctic marine environment is certainly characterized by extreme physical characteristics, most notably low water and air temperatures, annual extremes in light regime, wind speeds, disturbance and isolation. Yet, the Southern Ocean is the most thermally stable environment on Earth. Sea temperature fluctuation in Antarctica is seasonal, but unlike other environments, temperatures are remarkably stable in winter. Salinity in the Southern Ocean is also highly constant, even in near shore waters. The constraints for marine life are characterized by resource limitation associated with strong seasonality (Peck et al., 2005). Phytoplankton growth is restricted to a maximum of 3-4 summer months. Thus, the phytoplankton-dependent organisms endure a winter of low food supply. Unlike terrestrial species, marine organisms do not freeze and must, therefore, maintain physiologically active tissues throughout the year, utilizing strategies that minimize losses in winter (Peck et al., 2006).

\section{Literature review}

\section{Climate change in the Antarctic}

Climate change in Antarctica has been characterized by regional differences. So far the Western Antarctic Peninsula - the repository of most Antarctic terrestrial biodiversity is warming rapidly (Nicolas and Bromwich, 2014), partly due to the southern shift in the polar jet stream (fast flowing, narrow, meandering air current located near the altitude of the tropopause and westerly winds; Robinson and Erickson, 2014).

Temperature and water availability are the most important factors for the biology of Antarctic terrestrial organisms. Thus, even a small shift, especially in precipitation and liquid water availability, may have a profound biological impact on sensitive polar ecosystems (Chwedorzewska, 2009). Especially the maritime Antarctic region experiences the most pronounced and rapid changes regarding those factors. The 
temperature records collected in the Antarctic Peninsula region during the last fifty years show its warming by about $0.5^{\circ} \mathrm{C}$ per decade (Bromwich et al., 2013). This recent rapid regional temperature increase has caused glacier retreat (Smith et al., 1999), snow cover reduction (Fox and Cooper, 1998), an increase in the duration of the warm period and in the number of cumulative days with temperature above $0^{\circ} \mathrm{C}$ (Vaughan, 2006). Earlier spring thaws and later autumn freeze may have already significantly extended the vegetation season. Climate warming is also associated with an increase in availability of liquid water, which is more important for terrestrial communities than the increase in temperature alone. There were also changes in cyclonic activity patterns around the Antarctic, followed by changes in precipitation intensity and form (precipitation increasingly occurs as rain) (Bromwich et al., 2013; Kennedy, 1993; Quayle, 2003) with noticeable increase in total precipitation during the year (Turner et al., 2005). Beside direct precipitation, water availability in terrestrial habitats is governed by seasonal snow and glacial melt. In a range of maritime Antarctic sites, rapid rates of glacial melting and loss of 'permanent' snow banks have been observed (e.g. Fox and Cooper, 1998; Quayle, 2003). The increase in temperature cause rapid and earlier snow and ice cover melting, thus may exhaust freshwater reserves before the end of the vegetation season, increasing the risk of local drought. Furthermore, as the warming increases the frequency of winter thaws, it may lead to sub-snow ice layer formation on the ground surface, which has a destructive impact on terrestrial organisms (Arnold et al., 2003). Recently, a rapid glacier retreat in the whole Antarctic Peninsula region has been observed, causing emergence of vast postglacial areas (Favier et al., 2014). Permafrost is a very characteristic feature of Polar Regions. It restricts the water exchange to the active layer that thaws on a seasonal basis. Vegetation, the active layer, and the underlying permafrost are strongly linked, being key components of terrestrial ecosystems. Permafrost warming and active layer thickening were mainly attributed to mean air temperature rise, although in several cases the role of snow cover, soil properties and the overlying vegetation was emphasized (Romanovsky et al., 2010; Guglielmin et al., 2014). Over shorter timescales, the rise in temperature can have a strong effect on permafrost degradation. Withdrawal of permafrost due to warming increasingly contributes to nutrients loads in the subsurface waters. Soil frozen for thousands of years releases both water and nutrients, therefore seasonally the melt water can be extremely rich in biogenic elements, mainly phosphorus (Hobbie et al., 1999). Increased nutrient inflow has the potential to alter trophic interactions in Antarctic terrestrial ecosystems (e.g. Laybourn-Parry, 2003; Nędzarek et al., 2014). Deglaciation, intensification of weathering processes and permafrost decline, along with changes in the abundance of breeding populations of birds and pinnipeds (which have direct impact on the amount of nutrients transferred onto the land from the sea) cause dynamic changes in nutrient distribution and availability (e.g. Clarke et al., 2007; Smale and Barnes, 2008; Montes-Hugo et al., 2009). All those changes lead to a disturbance of terrestrial and freshwater communities, causing biodiversity decrease or/and changes in species composition. Huge amounts of meltwater coming from glaciers alter the freshwater balance in terrestrial ecosystems and at the same time generate an inflow of large amounts of nutrients to the sea. It also reduces the salinity of water in the coastal marine zone. Melting glaciers are causing a huge inflow of mineral suspension into the sea that results in silting of the bottom and affects the benthic communities as well as production of phytoplankton. At open sea, changes in the range of sea ice cover have been observed, which is also linked with the phytoplankton and zooplankton 
productivity (Clarke et al., 2007; Smale and Barnes, 2008). Furthermore, glacial meltwaters carry a substantial load of microbial cells. Castello and Rogers (2005) suggest that between $1 \times 10^{17}$ and $1 \times 10^{21}$ viable microorganisms are liberated each year by global glacier melt. Those microbes may have a profound influence on the composition of terrestrial and marine microbial communities, either by addition of highly competitive opportunists or providing genes of adaptive value (Świątecki et al., 2010; Dziewit et al., 2013; Zdanowski et al., 2013).

\section{Global human impact}

Antarctica is an area least affected by anthropogenic activity. However, recent regional rapid warming events of Western Antarctica have indicated that this area is as much affected by the impact of greenhouse gases like carbon dioxide, methane, nitrous oxide, ozone and chlorofluorocarbons as any other global site (Bargagli, 2008). Anthropogenic climate change not only directly affects the environment but also exerts other stressors.

The Southern Ocean circulation is a physicochemical boundary that isolates Antarctica from other oceans, therefore volatile contaminants reach Antarctica mainly via atmospheric transport from lower latitudes (Wania and Mackay, 1993; Wania, 2003; Choi et al., 2008). In the continental Antarctic, dense and cold air masses flow (katabatic winds) towards the coast. The katabatic drainage flow is compensated by the high troposphere air flow from the mid-latitudes, which also transports pollutants. This long-distance transport is affected both by circumpolar low-pressure systems and by the high pressure system over the Antarctic plateau (Shaw, 1998). This way, many Persistent Organic Pollutants (POPs) such as hexachlorobenzene, hexachlorocyclohexanes, aldrin, dieldrin, chlordane, endrin and heptachlor entered Antarctica and the Southern Ocean (e.g. www.unep.org). Snow precipitation is a very efficient mechanism for cleaning the air of airborne contaminants since snow can collect those compounds, transport them to the ground and accumulate in successive layers. Global distillation or fractionation by condensation in cold environments have been proposed as mechanisms whereby the Polar Regions may become sinks for some POPs (Wania and Mackay, 1993). Degradation of deposited POPs is very slow in the Polar Regions due to low temperatures and winter darkness. Most of the POPs get entrapped and incorporated into the Antarctic ice cap (Bennett et al., 2015).

POP concentrations in Antarctic organisms were generally low as compared to those reported for marine and terrestrial species at lower latitudes, and they are still among the lowest in the world. Yet, POPs are recorded in every level of the trophic chain and the phenomenon of biomagnification plays a more important role than the bioaccumulation itself (Szopińska et al., 2016), due to specific physiology and ecology of Antarctic organisms, especially their longer life spans. Top predators have a high risk of becoming sinks for POPS. Indeed, in some species the levels reported were occasionally high and comparable to those found in regions with a strong human impact (Corsolini, 2009).

\section{Direct human impacts}

Antarctica never had indigenous human populations. However, over the last 200 years, exploitation, exploration and research along with recent regional climate changes have significantly affected this remote region (Chwedorzewska, 2009). Some aspects of previous human disturbance of the Antarctic marine ecosystems still have particularly important implications, like the nineteen to mid-twentieth century commercial 
exploitation of fur seals and whales, which led to almost total extinction of these species in the Southern Ocean (Fraser et al., 1992).

In the last three decades, sudden development of scientific and tourist activity have been noted (Montes-Hugo et al., 2009; Chwedorzewska and Korczak, 2010). Every year a considerable number of tourists visit Antarctica, particularly the Antarctic Peninsula region (Figure 1). Combined with a number of scientific expeditions accompanied by huge amounts of cargo and equipment, human activity exerts noticeable impact on terrestrial ecosystems (Chwedorzewska and Korczak, 2010; Hughes et al., 2012). This activity requires the use of generators and heavy vehicles as well as construction of buildings, landing strips, roads, fuel reservoirs, etc. Waste disposal and incineration, sewage management and fuel combustion are further points of concern. Supply delivery to the stations, which usually takes place at the beginning of the Antarctic summer, are logistically complicated operations which require the use of heavy marine and land machinery to transport up to several thousand tons of cargo (Rakusa-Suszczewski and Krzyszowska, 1991). These procedures can have a strong effect on surrounding ecosystems, locally generating chemical pollution and directly damaging or altering soil, vegetation and freshwater ecosystems (Hale et al., 2008).

The highest impact has been reported around large stations like McMurdo Station, Ross Island (US Antarctic research centre) (Mazzera et al., 1999; Negri et al., 2006), whereas, according to research which has continued since the 1990s, the impact of small sized stations is rather minor (Rakusa-Suszczewski and Krzyszowska, 1991; Bargagli et al., 1998). Human activity associated with scientific research bases as well as with tourism concentrates mainly on small coastal ice-free areas with favourable topography and good microclimate condition (Rakusa-Suszczewski and Krzyszowska, 1991; Terauds et al., 2012) with developed tundra communities, and animal gathering sites (mainly huge breeding areas of sea birds and pinnipeds) (Chwedorzewska and Korczak, 2010). This combination indicates sites of high ecological value and sensitivity, which drastically magnifies the risk of deleterious human impacts.

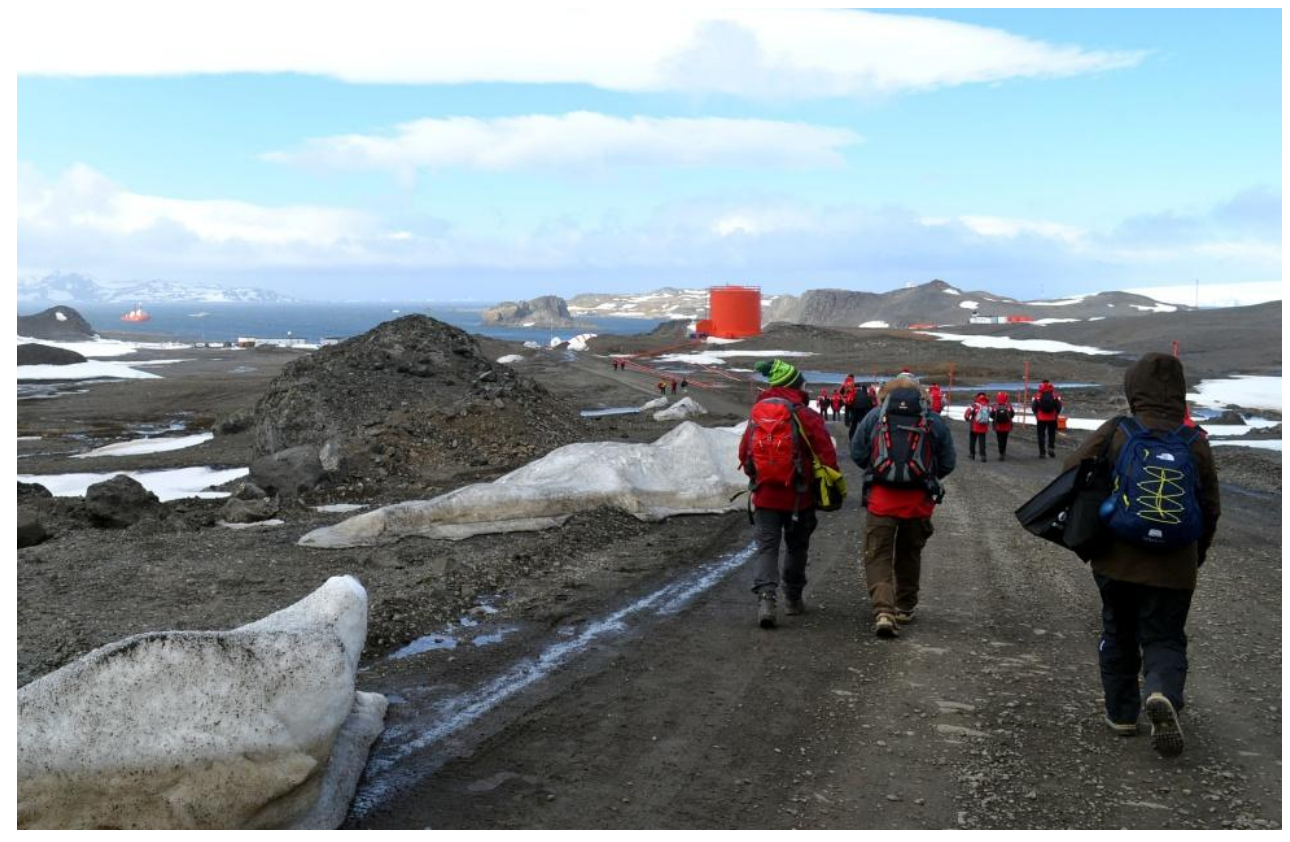

Figure 1. Tourists visiting Antarctic Station on King George Island (South Shetland Islands, Western Antarctica) in the austral summer (Photo: A. Znoj) 


\section{Biological contamination}

Human presence in the Antarctic also brings other threats, potentially even more dangerous for the ecosystem than POPs. Climate change along with increased human activity in this region create opportunities for some outside species to invade and colonize maritime Antarctic (Hughes and Worland, 2010; Hughes et al., 2012; Chwedorzewska et al., 2015). In spite of the significant number of tourists visiting the Antarctic Peninsula region (www.iaato.com), the main colonization events seem to be associated with the supply routes of polar stations rather than with tourism (Lee and Chown, 2009; Chwedorzewska and Korczak, 2010; Chown et al., 2012). Packing materials, vehicles, imported fresh foodstuffs, adhered soil, scientific equipment, building materials, clothing and footwear are considered as a potential vectors for alien species propagules (e.g. Lityńska-Zając et al., 2012; Augustyniuk-Kram et al., 2013; Chwedorzewska et al., 2013). On the other hand, due to amelioration of environmental condition of the Antarctic Peninsula region and changes in cyclonic activities (Kennedy, 1993), increased appearance of non-native birds species from lower latitudes was observed (e.g. Korczak-Abshire et al., 2011; Gryz et al., 2015) which can be responsible for the spread of alien propagules or/and pathogens threatening native species (Grimaldi et al., 2011).

\section{Rapid changes in Antarctic terrestrial ecosystem}

One of the most visible effects of climate change in the Antarctic Peninsula region is the fluctuation of sea ice coverage and dramatic glacier retreat (Bromwich et al., 2013). This process can lead to changes in ocean productivity, like alterations in plankton community composition and the most important changes in krill (Euphausia superba) recruitment and abundance (Ducklow et al., 2007). Krill, a key species of the whole Antarctic marine ecosystem, is also the biggest protein source in oceans and forms a critical trophic link between primary producers and upper-level consumers (fish, pinnipeds, cetaceans, and marine birds). Krill is also a very valuable commercial resource, intensively exploited from the early 70s (Nicol et al., 2012; Murphy et al., 2013). Stability of terrestrial communities is directly connected with constant supply of fertilizer from the sea - mainly droppings of breeding sea birds and pinnipeds (krill consumers). Population size fluctuations due to climate change (e.g. Korczak-Abshire et al., 2012; Korczak-Abshire et al., 2013) and fishery can directly influence terrestrial communities e.g. particularly the structure of ornithocoprophilous vegetation (Chwedorzewska and Korczak, 2010). Such fluctuation has been recently observed in Antarctic fur seals (Arctocephalus gazella), marked by a very rapid increase in population size to the levels that are greater than those existing before their exploitation in the nineteenth century. The presence of large numbers of fur seals on land has led to the rapid deterioration and changes in terrestrial tundra communities over large areas of ground accessible from the coast, where the majority of well-developed terrestrial ecosystems are found. It has also led to the rapid eutrophication of limnetic ecosystems accessible to the fur seals (Favero-Longo et al., 2011).

In the maritime Antarctic, development of terrestrial communities is controlled by extreme environmental conditions rather than biotic interactions. Those communities are expected to be very sensitive to changes in climate or consequential processes (Bargagli, 2005; Frenot et al., 2005). The consequences are thought to include increased diversity, biomass and trophic complexity, all of which enable development of a more 
complex ecosystem. Changes in the natural distribution ranges of native species or entire communities are also predicted. In the face of weakening natural barriers isolating Antarctica, it may be possible for single species or even whole communities to migrate from temperate zones to Polar Regions and shift the vegetation zones towards higher latitudes (Convey, 2006). Thus, most likely, further complications will arise from the complexity of species interactions. Some alien species transferred by humans may rapidly adapt to new conditions and engage in competition with native species (MolinaMontenegro et al., 2012). The most studied examples of such an event is the appearance and expansion of the annual meadow grass Poa annua (Figure 2) in the vicinity of the Antarctic stations situated along the Antarctic Peninsula (e.g. Wódkiewicz et al., 2013; 2014; Molina-Montenegro et al., 2014; Galera et al., 2015; 2016; Kellmann-Sopyła and Giełwanowska, 2015; Kellmann-Sopyła et al., 2015; Giełwanowska and KellmannSopyła, 2015). While the contemporary Antarctic biota show the ability to survive abiotic environmental extremes, its competitive abilities are very poorly developed and even whole communities are vulnerable to increased competition of opportunistic invaders (Bargagli, 2005; Chwedorzewska and Bednarek, 2011; Hughes et al., 2012; Androsiuk et al., 2015).

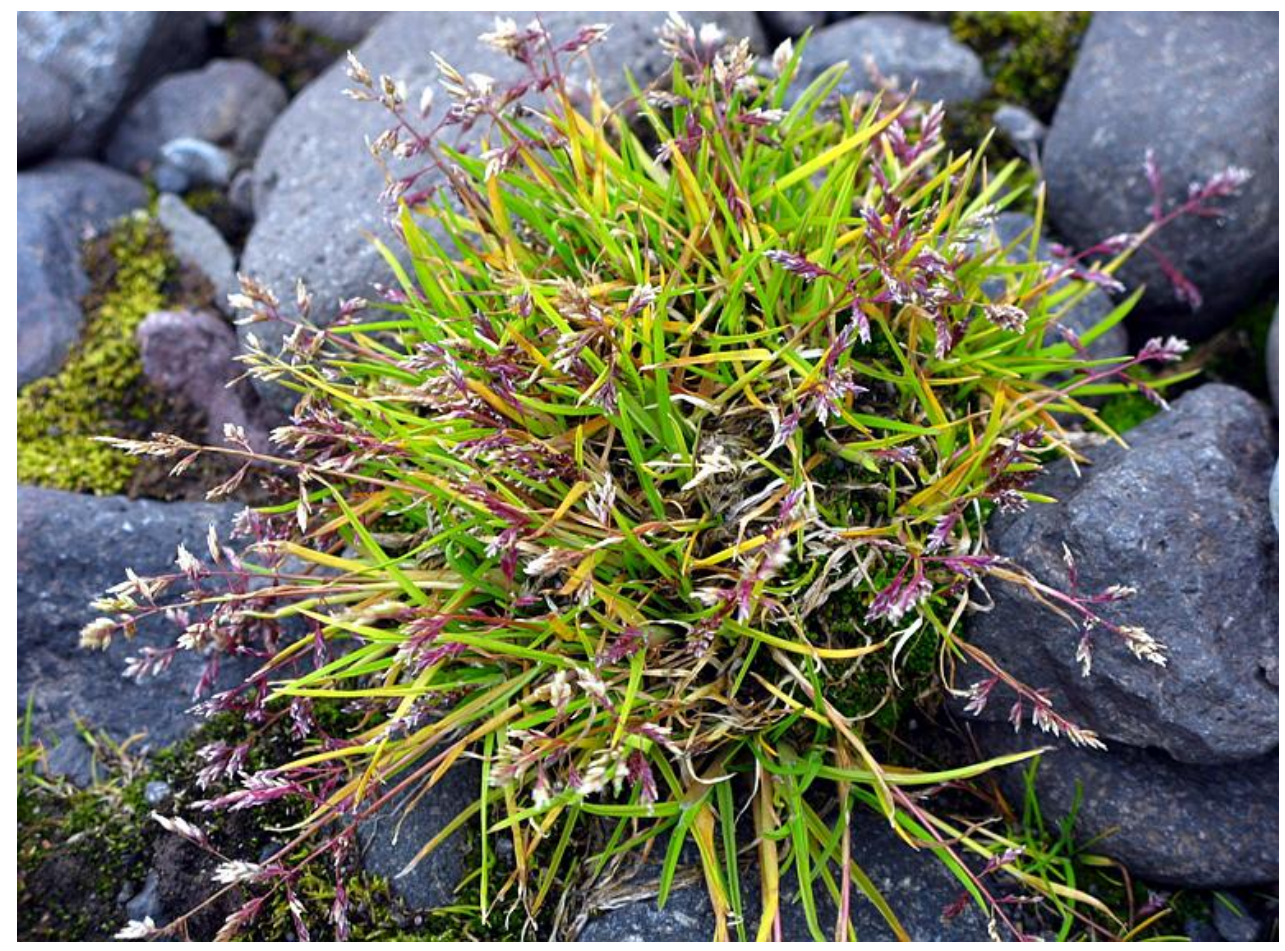

Figure 2. Poa annua in the vicinity of Polish Antarctic Station "Arctowski" on King George Island, South Shetland Islands, Western Antarctica (Photo: A. Znoj)

Expansion of the distribution ranges of indigenous species within Antarctica is also possible, since two native Antarctic species have been already identified as having longdistance dispersal potential (Convey and Lewis Smith, 1993) and are the most studied examples of a biological response to the recent environmental warming in maritime Antarctic (Convey and Lewis Smith, 1993; Gerighausen et al., 2003). Some populations have already increased by two orders of magnitude in size during the last three decades, and there has been a change in the balance of reproductive strategy utilization towards 
successful sexual reproduction by increasing the probability of establishment of germinating seedlings (Convey, 1996; McGraw and Day, 1997). A rapid increase in the population size has also been observed amongst bryophytes and microbiota in maritime Antarctic (Convey and Lewis Smith, 1993; Green et al., 1999). The most unpredictable and difficult to monitor is the appearance of alien microorganisms, including pathogens able to cause an epidemic (Kerry et al., 1999). Pollution, increased connectivity, and global environmental change affecting pathogens and their vectors' migration at high latitudes are likely to drive future disease emergence in this region (Grimaldi et al., 2011).

The most dramatic effect of climate warming in maritime Antarctic is the rapid retreat of glaciers (Zdanowski et al., 2013). Glacier forefields experience one of the most important vegetation changes: colonization and primary succession of huge areas devoid of vegetation uncovered from under the ice (Olech et al., 2011). Ice cap reduction may also profoundly increase the amount of mobile POPs contaminants entrapped so far in glaciers (secondary source of pollutants). Glacial melt may carry those pollutants to nearby lakes or coastal marine zones, thereby spreading them and increasing their entry into trophic webs (Rakusa-Suszczewski and Krzyszowska, 1991; Corsolini and Focardi, 2000; Ainley et al., 2005) causing increased POP accumulation in long-lived Antarctic organisms (Walther et al., 2002).

\section{Discussion}

Entire Antarctica, governed internationally by the decisions of the Antarctic Treaty countries, has a status of a natural reserve. Members of the Antarctic Treaty, the Consultative Parties, have committed themselves to the comprehensive protection of the Antarctic environment. The Protocol on Environmental Protection to the Antarctic Treaty (also known as the Madrid Protocol or Environmental Protocol, http://www.ats.aq/e/ep.htm) entered into force in 1998. This document puts in place a framework for the protection of Antarctica's environmental, scientific, historic, wilderness and aesthetic values. However, the Antarctic Protected Area system (http://www.ats.aq/documents/recatt/Att004_e.pdf) is still immature and further implementation of the existing management tools may be required to protect the diverse range of vulnerabilities, qualities and spatial scales represented in different fields of science (e.g. Hughes et al., 2015, 2016).

Conducting research on such a complex and remote ecosystem needs critical comparison over a long period. The main problem is that scientific activity in the Antarctic is very recent, for example, the first very robust meteorological records came from the 1950s from Faraday Station and the first data on the occurrence of anthropogenic pollutants comes from the 1960s. There are a lot of gaps in data sequences. Due to high costs of expeditions and very harsh environmental conditions, vast areas are still unexplored, with some places inaccessible. The development of Antarctic research has been conducted in fact for only a few decades, over which analytical methods have undergone continuous changes, thus making comparison with the oldest data very hard and sometimes even impossible. Often, information is scarce or lacking very crucial data, for example data concerning the biology of the sampled species, lack of knowledge of baseline conditions or concurrent natural phenomena that mask their effects, also research results are presented in various units, which makes them difficult to compare (Szopińska et al., 2016). 
Most importantly, in many fields, there is no proper long-term monitoring system, or it is only now being developing. Rapid changes in the Antarctic ecosystem are becoming a serious issue that needs to be more effectively investigated. In fact, in Antarctica, only the Commission for the Conservation of Antarctic Marine Living Resources (CCAMLR) manages sustainable fishery in this region, running very broad, long-term monitoring (CCAMLR Ecosystem Monitoring Program - CEMP), which started in the late eighties. CEMP's major function is to monitor the key life-history parameters of selected dependent species to detect changes in the abundance of those being harvested. 'Dependent species' are marine predators for which species targeted by commercial fisheries are a major component of their diet (https://www.ccamlr.org). Officially launched at the end of 2011 and still developing was the Southern Ocean Observation System (SOOS), which seems to fulfill the needs of a modern monitoring system. SOOS is an international initiative of the Scientific Committee on Antarctic Research (SCAR) and the Scientific Committee on Oceanic Research (SCOR). SOOS mission is to facilitate the collection and delivery of essential observations of dynamics and changes in the physical, chemical, geological and biological parameters of the Southern Ocean system to an all international scientific community to advance understanding of the Southern Ocean and to address critical societal challenges. The SOOS tries to develop a cyberinfrastructure, where marine assets would include a mixture of both autonomous and non-autonomous platforms. Combined with satellite remote sensing, the data would be relayed to ground stations in real time, where mathematical ocean models would produce near real-time state estimates of each of the parameters in the system (https://www.soos.aq).

\section{Conclusions}

Recent and historical selective overexploitation of some key species, unexpected increase in the population of some other, anthropogenic climate change, alien species pressure, local production and long distance transportation of pollutants, their accumulation in the ice cap and very slow degradation in polar conditions show that Antarctic ecosystems can no longer be regarded as pristine. Global anthropogenic activities along with local human influence weakened the barriers that isolate this continent from the rest of the world, causing an acceleration of the already observed changes. The main problem in such remote regions like Antarctica is that some consequences of human pressure may remain undetected because of the lack of monitoring systems, limited knowledge of baseline conditions or concurrent natural phenomena that mask their effects (Tin et al., 2014). Thus, it is very important to develop new effective monitoring systems. In Antarctica, the remote sensing techniques have opened up new opportunities for ecosystem monitoring. Satellites as well as manned and unmanned aircraft enable the collection of data from a local to global scale, which can be easily integrated with "ground" base data. The most promising seem to be very recent developments in the use of Unmanned Aerial Vehicles (UAVs) for remote sensing applications (e.g. Goetzendorf-Grabowski and Rodzewicz, 2016), which provide new opportunities for high-resolution ecosystem mapping and monitoring, but still, application of this technology to collect environmental data is a relatively new phenomenon in polar regions (e.g. Korczak-Abshire et al., 2016; Dąbski et al., 2017). 
Acknowledgements. This work was supported by the Polish Ministry of Scientific Research and Higher Education [grant number 2013/09/B/NZ8/03293].

\section{REFERENCE}

[1] Ainley, D. G., Clarke, D., Arrigo, K., Fraser, W. R., Kato, A., Barton, K. J., Wilson, P. R. (2005): Decadal-scale changes in the climate and biota of the Pacific sector of the Southern Ocean, 1950s to the 1990s. - Antarctic Sci. 17: 171-182.

[2] Androsiuk, P., Chwedorzewska, K. J., Szandar, K., Giełwanowska, I. (2015): Genetic variation of the Colobanthus quitensis from King George Island (Antarctica). - Pol. Polar Res. 36: 281-295.

[3] Arnold, R. J., Convey, P., Hughes, K. A., Wynn-Williams, D. D. (2003): Seasonal periodicity of physical and edaphic factors, and microalgae in Antarctic fellfields. - Polar Biol. 26: 396-403.

[4] Augustyniuk-Kram, A., Chwedorzewska, K. J., Korczak-Abshire, M., Olech, M., Lityńska-Zając, M. (2013) An analysis of fungal propagules transported to the Henryk Arctowski Station (Antarctica). - Pol. Polar Res. 34: 269-278.

[5] Bargagli, R. (2005): Antarctic ecosystems: environmental contamination, climate change, and human impact. - Springer-Verlag, Berlin

[6] Bargagli, R. (2008): Environmental contamination in Antarctic ecosystems. - Sci. Total Environ. 400: 212-226.

[7] Bargagli, R., Corsolini, S., Fossi, M. C., Sanchez-Henrnandez, J. C., Focardi, S. (1998): Antarctic fish Trematomus bernacchii as biomonitor of environmental contaminants at Terra Nova Bay Station (Ross Sea). - Mem. Natl. Inst. Polar Res. 52: 220-229.

[8] Barnes, D. K. A., Hodgson, D. A., Convey, P., Allen, C. S., Clarke, A. (2006): Incursion and excursion of Antarctic biota: past, present and future. - Global Ecol. Biogeogr. 15: 121-142.

[9] Bennett, J. R., Shaw, J. D., Terauds, A., Smol, J. P., Aerts, R., Bergstrom, D. M., Blais, J. M., Cheung, W. L. W., Chown, S. L., Lea, M. A., Nielsen, U. N., Pauly, D., Reimer, K. J., Riddle, M. J., Snape, I., Stark, J.S., Tulloch, V. J., Possingham, H. P. (2015): Polar lessons learned: long-term management based on shared threats in Arctic and Antarctic environments. - Front Ecol. Environ. 13: 316-324.

[10] Brey, T., Klages, M., Dahm, C., Gorny, M., Gutt, J., Hain, S., Stiller, M., Arntz, W. E., Wagele J. W, Zimmermann, A. (1994): Antarctic benthic diversity. - Nature, 368 (6469), 297-297

[11] Bromwich, D. H., Nicolas, J. P., Monaghan, A. J., Lazzara, M. A., Keller, L. M., Weidner, G. A., Wilson, A. B. (2013): Central West Antarctica among the most rapidly warming regions on Earth. - Nat. Geosci. 6: 139-145.

[12] Castello, J. D., Rogers, S. O. (2005): Life in ancient ice. - Princeton University Press, Princeton, New Jersey, USA.

[13] Choi, S., Baek, S-Y., Chang, Y-S., Wania, F., Ikonomou, M. G., Yoon, Y-J., Park, B-K., Hong, S. (2008): Passive Air Sampling of Polychlorinated Biphenyls and Organochlorine Pesticides at the Korean Arctic and Antarctic Research Stations: Implications for LongRange Transport and Local Pollution Environ. - Sci. Technol. 42: 7125-7131.

[14] Chown, S. L., Huiskes, A. H. L., Gremmen, N. J. M., Lee, J. E., Terauds, A., Crosbie, K., Frenote, Y., Hughes, K. A., Imura, S., Kiefer, K., Lebouvierh, M., Raymond, B., Tsujimoto, M., Warec, C., Van De Vijverk, B., Bergstrom, D. M. (2012): Continent-wide risk assessment for the establishment of nonindigenous species in Antarctica. - P. Natl. Acad. Sci. USA 109, 4983-4943.

[15] Chwedorzewska, K. J. (2009): Terrestrial Antarctic Ecosystems at the Changing World an overview. Pol. Polar Res. 30: 263-273. 
[16] Chwedorzewska, K. J., Bednarek, P. T. (2011): Genetic and epigenetic studies on populations of Deschampsia antarctica Desv. from contrasting environments at King George Island (Antarctic). - Pol. Polar Res., 32, 15-26.

[17] Chwedorzewska, K. J., Korczak, M. (2010): Human impact upon the environment in the vicinity of Arctowski Station, King George Island, Antarctica. - Pol. Polar Res. 31: 4560.

[18] Chwedorzewska, K. J., Korczak-Abshire, M., Olech, M., Lityńska-Zając, M., Augustyniuk-Kram, A. (2013): Alien invertebrates transported accidentally to the Polish Antarctic Station on cargo and fresh food. - Pol. Polar Res. 34: 55-66.

[19] Chwedorzewska, K. J., Giełwanowska, I., Olech, M., Wódkiewicz, M., MolinaMontenegro, M., Galera, H. (2015): Poa annua L. in the maritime Antarctic - an overview. - Polar Rec. 51: 637-643.

[20] Clarke, A., Barnes, D. K. A., Hodgson, D. A. (2005): How isolated is Antarctica? Trends Ecol. Evol. 20: 1-3.

[21] Clarke, A., \& Johnston, N. M. (2003): Antarctic marine benthic diversity. Oceanography and marine biology, 41: 47-114.

[22] Clarke, A., Johnston, N. M., Murphy, E. J., Rogers, A. D. (2007): Introduction. Antarctic ecology from genes to ecosystems: the impact of climate change and the importance of scale. - Phil. Trans. R. Soc. B 362: 5-9.

[23] Convey, P. (1996): The influence of environmental characteristics on life history attributes of Antarctic terrestrial biota. - Biol. Rev. 71: 191-225.

[24] Convey, P. (2000): How does cold constrain life cycles of terrestrial plants and animals? - Cryo Letters 21: 73-82.

[25] Convey, P. (2006): Antarctic climate change and its influences on terrestrial ecosystems. In: DM Bergstrom, P Convey, AHL Huiskes eds. Trends in Antarctic terrestrial and limnetic ecosystems: Antarctica as a global indicator. - Springer, Dordrecht: 253-272

[26] Convey, P., Chown, S.L., Clarke, A., Barnes, D.K.A., S., Cummings, V., Ducklow, H.W., Frati, F., Green, T. G. A., Gordon, S., Griffiths, H. J., Howard-Williams, C., Huiskes, A. H. L., Laybourn-Parry, J., Lyons, W. B., McMinn, A., Morley, S. A., Peck, L. S., Quesada, A., Robinson, S. A., Schiaparelli, S., Wall, D. H. (2014): The spatial structure of Antarctic biodiversity. - Ecol. Monogr. 84: 203-244.

[27] Convey, P., Lewis-Smith, R. I. L. (1993): Investment in sexual reproduction by Antarctic mosses. - Oikos 68: 293-302.

[28] Convey, P., Stevens-Hodgson, D. A., Smellie, J. L., Hillenbrand, C. D., Barnes, D. K. A., Clarke, A., Pugh, P. J. A., Linse, K., Craig Cary, S. (2009): Exploring biological constraints on the glacial history of Antarctica. - Quaternary Sci. Rev. 28: 3035-3048

[29] Corsolini, S. (2009): Industrial contaminants in Antarctic biota. - J. Chromatography A. 1216: 598-612.

[30] Corsolini, S., Focardi, S. (2000): Bioconcentration of polychlorinated biphenyls in the pelagic food chain of the Ross Sea - In: Guglielmo, L., Faranda, F., Ianora, L. (eds.) Ross Sea Ecology. Springer-Verlag, Berlin, 575-584.

[31] Dąbski, M., Zmarz, A., Pabjanek, P., Korczak-Abshire, M., Karsznia, I., Chwedorzewska K. J. (2017): UAV-based detection and spatial analyses of periglacial landforms on Demay Point (King George Island, South Shetland Islands, Antarctica). - Geomorph. 290 (1): 29-38.

[32] Ducklow, H. W., Baker, K., Martinson, D. G., Quetin, L. B. Ross, R. M., Smith, R. C., Stammerjohn, S. E., Vernet, M., Fraser, W. (2007): Marine pelagic ecosystems: the West Antarctic Peninsula. - Phil. Trans. R. Soc. B 362: 67-94.

[33] Dziewit, Ł., Grzesiak, J., Ciok, A., Nieckarz, M., Zdanowski, M. K., Bartosik, D. (2013): Sequence determination and analysis of three plasmids of Pseudomonas sp. GLE121, a psychrophile isolated from surface ice of Ecology Glacier (Antarctica). - Plasmid 70 (2): 254-262. 
[34] Favero-Longo, S. E., Cannone, N., Worland, M. R., Convey, P., Piervittori, R., Guglielmin, M. (2011): Changes in lichen vegetation with fur seal population increase on Signy Island (South Orkney Islands, Maritime Antarctic). - Antarct. Sci. 23: 65-77.

[35] Favier, L., Durand, G., Cornford, S. L., Gudmundsson, G. H., Gagliardini, O., GilletChaulet, F., Zwinger, T., Payne, A. J., Le Brocq, A. M. (2014): Retreat of Pine Island Glacier controlled by marine ice-sheet instability. - Nature Climate Change 4: 117-124.

[36] Fox, A. J., Cooper, A. P. R. (1998): Climate-Change Indicators from Archival Aerial Photography of the Antarctic Peninsula, Ann. - Glaciol. 27: 636-642.

[37] Fraser, W., Trivelpiece, W. Z., Ainley, D. G., Trivelpiece, S. G. (1992): Increases in Antarctic penguin populations: reduced competition with whales or a loss of sea ice due to environmental warming? - Polar. Biol. 11: 525-531.

[38] Frenot, Y., Chown, S. L., Whinam, J., Selkirk, P. M., Convey, P., Skotnicki, M., Bergstrom, D. M. (2005): Biological invasions in the Antarctic: extent, impacts and implications. - Biol. Rev. 80: 45-72.

[39] Galera, H., Chwedorzewska, K. J., Wódkiewicz, M. (2015): Response of Poa апnиа to extreme conditions: comparison of morphological traits between populations from cold and temperate climate conditions. - Polar Biol. 38: 1657-1666.

[40] Galera, H., Wódkiewicz, M., Czyż, E., Łapiński, S., Kowalska, M. E., Pasik, M., Rajner, M., Bylina, P., Chwedorzewska, K. J. (2016): First step to eradication of Poa annua L. from Point Thomas Oasis (King George Island, South Shetlands, Antarctica). - Polar Biol. DOI 10.1007/s00300-016-2006-y

[41] Goetzendorf-Grabowski, T., Rodzewicz, M. 2016. Design of UAV for photogrammetric mission in Antarctic area. Challenges in European Aerospace. - Proceedings of the Institution of Mechanical Engineers Part G Journal of Aerospace Engineering 1-16. Doi:10.1177/0954410016656881

[42] Gerighausen, U., Brautigam, K., Mustafa, O., Peter, H. U. (2003): Expansion of vascular plants on an Antarctic island - a consequence of climate change? - In: Huiskes A. H. L, Gieskes, W. W. C., Rozema, J., Schorno, R. M. L., van der Vies, S. M., Wolff, W. J. (eds.). Antarctic biology in a global context, Backhuys, Leiden, 79-83.

[43] Giełwanowska, I., Kellmann-Sopyła, W. (2015): Generative reproduction of Antarctic grasses, the native species Deschampsia antarctica Desv and the alien species Poa annua L. - Pol. Polar Res. 36: 261-279.

[44] Giełwanowska, I., Szczuka, E. (2005): New ultrastructural features of organelles in leaf cells of Deschampsia antarctica Desv. - Polar Biol. 28: 951-955.

[45] Green, T. G. A., Schroeter, B., Sancho, L. G. (1999): Plant life in Antarctica. - In: Pugneres, F. I., Valladeres, F. (eds.) Handbook of plant Ecology. Basel, New York: 495543

[46] Grimaldi, W. W., Seddon, P. J., Lyver, P. O’B., Nakagawa, S., Tompkins, D. M. (2011): Infectious diseases of Antarctic penguins: current status and future threats. - Polar Biol. 38: 591-608.

[47] Gryz, P., Korczak-Abshire, M., Gerlée, A. (2015): First record of Austral Negrito (Lessonia rufa) from the South Shetland Islands, the Antarctic. - Pol. Polar Res. 36: 297304.

[48] Guglielmin, M., Fratte, M. D., Cannone, C. (2014): Permafrost warming and vegetation changes in continental Antarctica. - Environ. Res. Lett. 9: 045001: 14.

[49] Hale, R. C., Kim, S. L., Harvey, E., La Guardia, M. J., Mainor, T. M., Bush, E. O., Jacobs, E. M. (2008): Antarctic research bases: local sources of polybrominated diphenyl ether (PBDE) flame retardants. - Environ. Sci. Technol. 42: 1452-1457.

[50] Hobbie, J. E., Peterson, B. J., Bettez, N., Deegan, L., O'Brien, W. J., Kling, G. W., Kipphut, G. W., Bowden, W. B., Hershey, A. E. (1999): Impact of global change on the biogeochemistry and ecology of an Arctic freshwater system. - Polar Res. 18: 207-214. 
[51] Hughes, K. A., Ireland, L. C., Convey, P., Fleming, A. H. (2015): Assessing the effectiveness of specially protected areas for conservation of Antarctica's botanical diversity. - Conserv. Biol. 30: 113-120.

[52] Hughes, K. A., López-Martínez, J., Francis, J. E., Alistair, J., Crame, A., Carcavilla, L., Shiraishi, K., Hokada, T., Yamaguchi, A. (2016): Antarctic geoconservation: a review of current systems and practices. - Environ. Conserv. doi:10.1017/S0376892915000387

[53] Hughes, K. A., Worland, M. R. (2010): Spatial distribution, habitat preference and colonization status of two alien terrestrial invertebrate species in Antarctica. - Antarctic Sci. 22: 221-231.

[54] Hughes, K. A., Worland, M. R., Thorne, M. A. S., Convey, P. (2012): The non-native chironomid Eretmoptera murphyi in Antarctica: erosion of the barriers to invasion. Biol. Invasions 15: 269-281.

[55] Kellmann-Sopyła, W., Giełwanowska, I. (2015): Germination capacity of five polar Caryophyllaeae and Poaceae species under different temperature conditions. - Polar. Biol. 38: 1753-1765.

[56] Kellmann-Sopyła, W., Lahuta, L. B., Giełwanowska, I., Górecki, R.J. (2015): Soluble carbohydrates in developing and mature diaspores of polar Caryophyllaceae and Poaceae. - Acta Physiol Plant DOI 10.1007/s11738-015-1866-z.

[57] Kennedy, A. D. (1993): Water as a limiting factor in the Antarctic terrestrial environment: a biogeographical synthesis. - Arct. Alpine Res. 25: 308-315.

[58] Kerry, K., Riddle, M., Clarke, J. (1999): Diseases of Antarctic Wildlife. A Report for The Scientific Committee on Antarctic Research (SCAR) and The Council of Managers of National Antarctic Programs (COMNAP), 1-104.

[59] Korczak-Abshire, M., Angiel, P. J., Wierzbicki, G. (2011): Records of white-rumped sandpiper (Calidris fuscicollis) on the South Shetland Islands. - Polar. Rec. 47: 262-267.

[60] Korczak-Abshire, M., Chwedorzewska, K. J., Wąsowicz, P., Bednarek, P. T. (2012): Genetic structure of declining chinstrap penguin (Pygoscelis antarctica) populations from South Shetland Islands (Antarctica). - Polar Biol. 35: 1681-1689.

[61] Korczak-Abshire, M., Kidawa, A., Zmarz, A., Storvold, R., Karlsen, S-R., Rodzewicz, M., Chwedorzewska, K. J., Znój, A. (2016): Preliminary study on nesting Adelie penguins disturbance by Unmanned Aerial Vehicles. - CCAMLR-Science 23: 1-16.

[62] Korczak-Abshire, M., Węgrzyn, M., Angiel, P. J., Lisowska, M. (2013): Pygoscelid penguins breeding distribution and population trends at Lions Rump rookery, King George Island. - Pol. Polar Res., 34: 87-99.

[63] Laybourn-Parry, J. (2003): Polar limnology, the past, the present and the future. - In: Huiskes, A. H. L., Gieskes, W. W. C., Rozema, J., Schorno, R. M. L., van der Vies, S. M., Wolff, W. J. (eds.) Antarctic Biology in a Global Context, Backhuys Publishers, Leiden, 321-329.

[64] Lee J. E., Chown S. L. (2009): Breaching the dispersal barrier to invasion: quantification and man agement. - Ecol. Appl. 19: 1944-1959.

[65] Lityńska-Zając, M., Chwedorzewska, K. J., Olech, M., Korczak-Abshire, M., Augustyniuk-Kram, A. (2012): Diaspores and phyto-remains accidentally transported to the Antarctic Station during three expeditions. - Biodivers. Conserv. 21: 3411-3421.

[66] Mazzera, D. M., Hayes, T., Lowenthal, D. H., Zielinska, B. (1999): Quantification of polycyclic aromatic hydrocarbons in soil at McMurdo Station, Antarctica. - Sci. Total Environ. 229: 65-71.

[67] McGraw, J. B., Day, T. A. (1997): Size and characteristics of a natural seed bank in Antarctica. - Arct. Alp. Res. 29: 213-216.

[68] Molina-Montenegro, M. A., Carrasco-Urra, F., Rodrigo, C., Convey, P., Valladares, F., Gianoli, E. (2012): Occurrence of the non-native annual bluegrass on the Antarctic mainland and its negative effects on native plants. - Conserv. Biol. 26: 17-723.

[69] Molina-Montenegro, M. A., Carrasco-Urra, F., Acuña-Rodríguez, I., Oses R., Chwedorzewska, K. J. (2014): Assessing the importance of human activities for the 
establishment of the invasive Poa annua in the Antarctica. - Polar Res. 33: 21425, http://dx.doi.org/10.3402/polar.v33.21425

[70] Montes-Hugo, M., Doney, S. C., Ducklow, H. W., Fraser, W., Martinson, D., Stammerjohn, S. E., Schofield, O. (2009): Recent Changes in Phytoplankton Communities Associated with Rapid Regional Climate Change Along the Western Antarctic Peninsula. - Science 323: 1470-1473.

[71] Murphy, E. J., Hofmann, E. E., Watkins, J. L., Johnston, N. M., Piñones, A., Ballerini, T., Hill, S. L., Trathan, P. N., Tarling, G. A., Cavanagh, R. A., Young, E. F., Thorpe, S. E., Fretwell, P. (2013): Comparison of the structure and function of Southern Ocean regional ecosystems: The Antarctic Peninsula and South Georgia. - J. Marine Syst. 109-110: 2242.

[72] Nędzarek, A., Tórz, A., Drost, A. (2014): Selected elements in surface waters of Antarctica and their relations with the natural environment. - Polar Res. 33: 21417, http://dx.doi.org/10.3402/polar.v33.21417

[73] Negri, A., Burns, K., Boyle, S., Brinkman, D., Webster, N. (2006): Contamination in sediments, bivalves and sponges of McMurdo Sound, Antarctica. - Environ. Pollut. 143: 456-67.

[74] Nicol, S., Foster, J., Kawaguchi, S. (2012): The fishery for Antarctic krill - recent developments. - Fish Fish. 13: 30-40.

[75] Nicolas, J. P., Bromwich, D. H. (2014): New reconstruction of Antarctic near-surface temperatures: multidecadal trends and reliability of global reanalyses. - J. Climate 27: 8070-8093.

[76] Ochyra, R., Lewis Smith, L. R. I, Bednarek-Ochyra, H. (2008): The illustrated moss flora of Antarctica. - Cambridge University Press, Cambridge: 685.

[77] Olech, M. (2004): Lichens of King George Island Antarctica. - The Institute of Botany of the Jagiellonian University, Cracow: 391.

[78] Olech, M., Węgrzyn, M., Lisowska, M., Słaby, A., Angiel, P. (2011): Contemporary changes in vegetation of polar regions. - Papers on Global Change IGBP 18: 35-51.

[79] Peck, L. S. (2005): Prospects for surviving climate change in Antarctic aquatic species. Frontiers in Zoology 2:9 doi:10.1186/1742-9994-2-9

[80] Peck, L. S., Convey, P., Barnes, D. K. A. (2006): Environmental constraints on life histories in Antarctic ecosystems: tempos, timings and predictability. - Biol. Rev. 81: 75109.

[81] Quayle, W. C., Convey, P., Peck, L. S., Ellis-Evans, J. C., Butler, H. G., Peat, H. J. (2003): Ecological responses of maritime Antarctic lakes to regional climate change. Antarct. Res. Ser. 79: 159-170.

[82] Rakusa-Suszczewski, S., Krzyszowska, A. (1991): Assesment of the environmental impact of the "H. Arctowski" Polish Antarctic Station (Admiralty Bay, King George Island, South Shetland Islands). - Pol. Polar Res. 12: 105-121.

[83] Robinson, S. A., Erickson, D. J. (2014): Not just about sunburn - the ozone hole's profound effect on climate has significant implications for Southern Hemisphere ecosystems. - Glob. Change Biol. 21: 515-27.

[84] Romanovsky, V. E., Smith, S. L., Christiansen, H. H. (2010): Permafrost thermal state in the polar Northern Hemisphere during the International Polar Year 2007-2009: a synthesis. - Permafrost Periglac. Process. 21: 106-16.

[85] Siciński, J., Jażdźewski, K., De Broyer, C., Presler, P., Ligowski, R., Nonato, E. F., Corbisier, T. N., Petti, M. A. V., Brito, T. A. S., Lavrado, H. P., Błażewicz-Paszkowycz, M., Pabis, K., Jażdżewska A., Campos, L. S. (2011): Admiralty Bay benthos diversity-a census of a complex polar ecosystem. - Deep-Sea Research II 58: 30-48.

[86] Shaw, G. E. (1998): Antarctic aerosol: a review. - Rev. Geophys 26: 89-112.

[87] Smale, D. A., Barnes, D. K. A. (2008): Likely responses of the Antarctic benthos to climate-related changes in physical disturbance during the 21st century, based primarily on evidence from the West Antarctic Peninsula region. - Ecography 31: 289-305. 
[88] Smith, V. R., Ainley, D., Baker, K., Domack, E., Emslie, S., Fraser, B., Kennett, J., Leventer, A., Mosley-Thompson, E., Stammerjohn, S., Vernet, M. (1999): Marine Ecosystem Sensitivity to Climate Change - Historical Observations and Paleoecological Records Reveal Ecological Transitions in the Antarctic Peninsula Region. - Biosci. 40: 393-404.

[89] Szopińska, M., Namieśnik, J., Polkowaka, Ż. (2016): How important is research on pollution levels in Antarctica? Historical approach difficulties and current trends. Reviews of Environmental Contamination and Toxicology Rev. Environ. Contam. T. doi 10.1007/398_2015_5008

[90] Świątecki, A., Górniak, D., Jankowska, K., Zdanowski, M. K., Borsuk, P., ŻmudaBaranowska, M. J., Grzesiak, J. (2010): Effects of climate change on microbial community structure and function in the Antarctic glacier lagoon. - Papers on Global Change 17: 7-15.

[91] Terauds, A., Chown, S. L., Morgan, F., Peat, J., Watts, H., Keys, D. J., Convey, P., Bergstrom, D. M. (2012): Conservation biogeography of the Antarctic. - Divers Distrib. 18: 726-741.

[92] Tin, T., Lamers, M., Liggett, D., Maher, P. T., Hughes, K. A. (2014): Setting the Scene: Human Activities, Environmental Impacts and Governance Arrangements in Antarctica. In: Tin, T., Liggett, D., Maher, P. T., Lamers, M. (eds.) Antarctic Future, Human Engagement with the Antarctic environment, 1-26.

[93] Tufto, J. (2000): The Evolution of Plasticity and Nonplastic Spatial and Temporal Adaptations in the Presence of Imperfect Environmental Cues. - Am Nat 156: 121-130

[94] Turner, J., Colwell, S. R., Marshall, G. J., Lachilan-Cope, T. A., Carleton, A. M., Jones, P. D., Lagun, V., Reid, P. A. (2005): Iagovkuna S Antarctic climate change during the last 50 years. - Int. J. Climatol. 25: 279-294.

[95] UNEP United Nations Environmental Programme www.unep.org, 2002.

[96] Vaughan, D. G. (2006): Trends in melting conditions on the Antarctic Peninsula and their implications for ice sheet mass balance, Arct. Antarct. - Alpine Res. 38: 147-152.

[97] Walther, G. R., Post, E., Convey, P., Menzel, A., Parmesank, C., Beebee, T. J. C., Fromentin, J-M., Hoegh-Guldberg, O., Bairlein, F. (2002): Ecological responses to recent climate change. - Nature 416: 389-395.

[98] Wania, F. (2003): Assessing the Potential of Persistent Organic Chemicals for LongRange Transport and Accumulation in Polar Regions Environ. - Sci. Technol. 37: 13441351.

[99] Wania, F., Mackay, D. (1993): Global Fractionation and Cold Condensation of Low Volatility Organochlorine Compounds in Polar Regions. - Ambio 22: 10-18.

[100] Wasley, J., Robinson, S. A., Lovelock, C. E., Popp, M. (2006): Some like it wet - an endemic Antarctic bryophyte likely to be threatened under climate change induced drying.- Funct. Plant Biol. 33: 443-455.

[101] Wódkiewicz, M., Galera, H., Giełwanowska, I., Chwedorzewska, K. J., Olech, M. (2013): Diaspores of the introduced species Poа апnиа L. in soil samples from King George Island (South Shetlands, Antarctic). - Arct Antarct Alp. Res. 45: 415-419.

[102] Wódkiewicz, M., Ziemiański, M., Kwiecień, K., Chwedorzewska, K. J., Galera, H. (2014): Spatial structure of the soil seed bank of Poa апnиа L. - alien species in the Antarctica. - Biodivers Conserv. 23: 1339-1346.

[103] Zdanowski, M. K., Zmuda-Baranowska, M. J., Borsuk, P., Świątecki, A., Górniak, D., Wolicka, D., Jankowska, K. M., Grzesiak, J. (2013): Culturable bacteria community development in postglacial soils of Ecology Glacier, King George Island, Antarctica. Polar Biol. 36:511-527. 